\title{
Determination of amino acid profile of mare milk produced in the highlands of the Kyrgyz Republic during the milking season
}

\author{
A. T. Mazhitova ${ }^{1}$ and A. A. Kulmyrzaev \\ Department of Food Engineering, Kyrgyz-Turkish Manas University, Bishkek 720038, Kyrgyzstan
}

\begin{abstract}
This study was carried out to determine the influence of milking season on amino acid (AA) profile and chemical composition of milk samples from Kyrgyz native breed mares under traditional pasture conditions. Milk samples were collected monthly from May to August 2014 from mares grazing at 2,200 m above sea level. The AA composition was determined by precolumn derivatization with diethyl ethoxymethylenemalonate in HPLC and 18 AA were determined in mare milk. The analytical parameters of linearity $(0.01-4 \mu \mathrm{g} / \mathrm{mL})$, precision of the method $(0.26-4.88 \%$ relative standard deviation), derivatization procedure $(0.82-2.80 \%$ relative standard deviation), and instrument precision (0.08$1.00 \%$ relative standard deviation) were determined. The most abundant AA were glutamic acid (0.393-480 $\mathrm{g} / 100 \mathrm{~g}$ of milk), leucine (0.192-0.230 g/100 g of milk), and lysine $(0.192-0.230 \mathrm{~g} / 100 \mathrm{~g}$ of milk). The amount of ornithine was small $(0.002-0.015 \mathrm{~g} / 100 \mathrm{~g}$ of milk). The percentages of essential AA in the protein of mare milk were 46, 46, 51, and $48 \%$ for May, June, July, and August, respectively, which demonstrate the high biological value of milk during the whole milking season.
\end{abstract}

Key words: amino acid, high performance liquid chromatography, mare milk, milking season

\section{INTRODUCTION}

Milk is one of the highest grade products in the human diet (Hambraus, 1993). Milk contains all essential bioactive components because its primary function is the healthy growth of the newborn. According to nutritional and physiological requirements of neonates, these components changed during the period of lactation (Park, 2009; O'Mahony and Fox, 2014). Milks of various species differ quantitatively and qualitatively according to constituents (Fox and McSweeney, 1998;

Received April 16, 2015.

Accepted December 15, 2015.

${ }^{1}$ Corresponding author: mazhitova.aichurok@mail.ru
Malacarne et al., 2002). The composition of mare milk is significantly different from the composition of milk from cows and other animals (Davis et al., 1994; Doreau and Martuzzi, 2006). According to the values and composition of mare milk proteins, mare milk belongs to the group of albumin milk; it contains about $50 \%$ casein and about $40 \%$ whey protein (Csapó-Kiss et al., 1995; Potočnik et al., 2011). Due to the high content of milk whey proteins, mare milk is a rich source of EAA and has a high biological value; its true digestibility is 95 to $97 \%$ (WHO, 2002; Čagalj et al., 2014; Zhan et al., 2014). Balanced AA composition of milk provides healthy growth of the human body (Stanton et al., 2013).

Mare milk is the main raw material for koumiss preparation. Koumiss is a traditional fermented dairy drink of the central Asian people (Kucukcetin et al., 2003; Cagno et al., 2004). The high nutritional properties of koumiss derive from the composition of mare milk, which is used for its preparation ( $\mathrm{Lv}$ and Wang, 2009; Zhan et al., 2014). Therefore, the study of the AA composition to determine the biological value of the mare milk is important because it is the raw material for koumiss and mare milk, by itself, is a nutritious drink.

Isolation of AA from milk samples is generally based on hydrolysis with $6 \mathrm{~N} \mathrm{HCl}$ and derivatization of isolated AA is based on the detector used (Sabahelkheir et al., 2012).

The most frequently used reagents in pre-column derivatization of AA in the milk protein hydrolysates are phenylisothiocyanate, o-phthaldehyde for primary AA and 9-fluorenylmethyl chloroformate for secondary AA, which yields derivates detectable by UV and also 6-aminoquinolyl- $N$-hydroxysuccinimidyl carbamate, $o$-phthaldialdehyde reaction using the chiral $\mathrm{N}$-acetylL-cysteine reagent, which yields derivates detectable by fluorescence detection (Davis et al., 1994; Bosch et al., 2006; Rubio-Barroso et al., 2006; Rudenko et al., 2009; Marino et al., 2010).

Derivatization with diethyl ethoxymethylenemalonate (DEEMM) and spectrophotometric detection at $280 \mathrm{~nm}$ was used for determination of AA composition 
of honey samples (Hermosin et al., 2003; Rebane and Herodes, 2010), but was not applied in milk samples.

The most abundant AA in mare milk are glutamic acid (10.87-20.87 g/100 g of protein), lysine (6.23-10.0 $\mathrm{g} / 100 \mathrm{~g}$ of protein), leucine $(7.6-9.83 \mathrm{~g} / 100 \mathrm{~g}$ of protein), and aspartic acid (7.11-10.4 g/100 $\mathrm{g}$ of protein), and the least abundant AA are cysteine $(0.2-2.27 \mathrm{~g} / 100$ $\mathrm{g}$ of protein), glycine (1.43-2.00 g/100 $\mathrm{g}$ of protein), and tryptophan $(0.20-1.4 \mathrm{~g} / 100 \mathrm{~g}$ of protein; Doreau and Boulot, 1989; Csapó-Kiss et al., 1995; Minjigdorj et al., 2012). These values vary according to the lactation period (Csapó-Kiss et al., 1995), method of analysis (Doreau and Boulot, 1989), ecological region, and milking season (Minjigdorj et al., 2012). Mare milk has very strong seasonal traits. In Kyrgyzstan mares are milked in late spring from May to early autumn, when mares graze in pastures. Therefore, milking season lasts 4 or 5 mo a year.

Few reliable data are available on AA composition of mare milk. The aim of the present study was to determine the changes in AA composition of mare milk collected from the highlands $(2,200 \mathrm{~m}$ above sea level) of the Kyrgyz Republic during the milking season. The investigation of AA composition of the milk of Kyrgyz mares kept under traditional extensive pasture conditions and without any form of dietary supplements makes this research interesting.

\section{MATERIALS AND METHODS}

\section{Reagents and Standards}

The HPLC-grade acetonitrile, acetic acid, L-aspartic acid, L-glutamic acid, DL-serine, L-histidine, glysine, L-threonine, L-arginine, L-alanine, L-tyrosine, L-valine, L-methionine, L-isoleucine, L-leucine, L- phenylalanine, L-ornithine monohydrochloride, L-lysine monohydrochloride, 4-aminobutyric acid (as internal standard), and DEEMM were obtained from Merck (Darmstadt, Germany). High-purity water was supplied by the PURELAB Option-Q system from Elga Veolia (High Wycombe, UK); sodium acetate was purchased from Carlo Erba Reagents (Val-de-Reuil, France); and Ltryptophan was purchased from Carl Roth (Karlsruhe, Germany).

\section{Samples}

Milk samples were collected monthly from May to August from 25 mares of the Kyrgyz native breed that foaled during the period from February to April in one of the horse farms in the region of Suusamyr (northern Kyrgyz Republic). Suusamyr pasture is located at an altitude of $2,200 \mathrm{~m}$ above sea level. The pastures in this region are used for grazing by cattle, horses, and small ruminants. Mares were on pasture of good quality from spring to autumn without any form of concentrate supplementation.

Milk samples immediately after machine milking were collected in 100-mL Premium Glass bottles with screw caps (Duran Group, Wertheim, Germany) and submerged to liquid nitrogen in a transportable Dewar flask (Cole-Parmer, Karlsruhe, Germany). The samples were kept at $-20^{\circ} \mathrm{C}$ in a deep freezer until analysis in the laboratory.

\section{Sample Preparation}

At the time of analysis, the frozen material was thawed in a $30^{\circ} \mathrm{C}$ water bath and mixed thoroughly. The protein content (Kjeldahl) of milk was determined by AOAC International (2000) method no. 991.22.

Amino acids were isolated from milk samples according to the method described by Bosch et al. (2006); $0.666 \mathrm{~g}$ of milk sample was treated with $5 \mathrm{~mL}$ of $6 \mathrm{~N}$ $\mathrm{HCl}$ and flushed under nitrogen for $1 \mathrm{~min}$ to remove air. Hydrolysis was then carried out at $110^{\circ} \mathrm{C}$ for $23 \mathrm{~h}$. After tubes cooled to room temperature, the content was filtered through wet filter paper to a $200-\mathrm{mL}$ volumetric flask, and $3.6 \mathrm{~mL}(1,000 \mu \mathrm{g} / \mathrm{mL})$ of stock solution of internal standard (4-aminobutiyric acid) was added and diluted to volume. The final concentration of internal standard was $3 \mu \mathrm{g} / \mathrm{mL}$.

The derivatization procedure was the same as used by Hermosin et al. (2003) for honey samples with some modifications. Three microliters of DEEMM, $0.75 \mathrm{~mL}$ of methanol, $0.5 \mathrm{~mL}$ of the solution of isolated AA, and $1.747 \mathrm{~mL}$ of borate buffer ( $1 \mathrm{M}$, pH 9.0 ) were placed in a $10-\mathrm{mL}$ tube with a screw cap. After closing, the tube was briefly shaken and the tube was placed in an ultrasound bath for $30 \mathrm{~min}$ at room temperature. Derivatives were stable at room temperature for up to $1 \mathrm{wk}$.

\section{Chemical Analysis}

Total solids were determined by direct forced-air oven drying method at $100^{\circ} \mathrm{C}$ throughout the $4 \mathrm{~h}$ (AOAC International 990.20, 2000). Fat in raw milk was measured using the Babcock method (989.04, AOAC International, 2000) and ash content of samples was determined using the gravimetric method after ignition in a muffle furnace at $550^{\circ} \mathrm{C}$ until ash is $\mathrm{C}$ free $(945.46$, AOAC International, 2000). The $\mathrm{pH}$ was measured by a digital pH meter (model $220 \mathrm{pH} /$ Conductivity Meter, Denver Instrument Company, Denver, CO) and titratable acidity was measured using the titrimetric method (CIS, 2001). 
Table 1. Elution gradient used for AA determination ${ }^{1}$

\begin{tabular}{lcc}
\hline Time, min & A, $\%$ & B, \% \\
\hline 0 & 6 & 94 \\
13 & 16 & 84 \\
13.5 & 18 & 82 \\
17 & 18 & 82 \\
20 & 22 & 78 \\
32 & 32 & 68 \\
\hline
\end{tabular}

${ }^{1} \mathrm{~A}=$ acetonitrile; $\mathrm{B}=$ acetate buffer.

\section{Analytical Method}

Derivatized samples were filtered through $0.45-\mu \mathrm{m}$ syringe filter to $1.5-\mathrm{mL}$ vials and injected to a High Performance Liquid Chromatography System (Agilent Technologies 1200, Santa Clara, CA) that consisted of a degasser (G1322A), quaternary pump (G1311A), ALS autosampler (G1329A), thermostated column compartment (G1316A), and diode array detector (G1315D).

Chromatographic separation was carried out in a C18 $(4.6 \mathrm{~mm} \times 250 \mathrm{~mm} \times 5 \mu \mathrm{m})$ column. The column was thermostated at $16^{\circ} \mathrm{C}$ and the flow rate was $1.0 \mathrm{~mL} /$ min. The injection volume was $20 \mu \mathrm{L}$. Mobile phase A was acetonitrile and $\mathrm{B}$ acetate buffer $(0.1 M)$ at $\mathrm{pH} 6.0$ according to gradient conditions shown in Table 1 (Hermosin et al., 2003). Detection was carried out by DAD (diode array detector) at $280 \mathrm{~nm}$. Identification was made by means of the retention times obtained from pure compounds. Quantification was achieved on the basis of internal standard method. The AA contents were estimated as follows:

$$
\mathrm{Ci}=\frac{\mathrm{Ai}}{\mathrm{As}} \times \mathrm{Cs} \times \mathrm{RF}
$$

where $\mathrm{Ci}=\mathrm{AA}$ content in $\mu \mathrm{g} / \mathrm{mL} ; \mathrm{Ai}=\mathrm{AA}$ area in sample; As = internal standard area; $\mathrm{Cs}=$ concentration of internal standard $(3 \mu \mathrm{g} / \mathrm{mL})$; and $R F=$ response factor. Linearity test solutions were prepared at concentration levels ranging from $0.01,0.5,1,2,3$, and
$4 \mu \mathrm{g} / \mathrm{mL}$ of each AA added with $3 \mu \mathrm{g} / \mathrm{mL}$ of internal standard and derivatized according to the procedure described previously.

\section{Statistical Analysis}

Data were analyzed by ANOVA using SPSS software, version 16.0 (SPSS Inc., Chicago, IL). The differences between the means of the treatments were compared using Duncan's test at a significance level of $P=0.01$ and $P=0.05$.

\section{RESULTS AND DISCUSSION}

\section{Chemical Composition}

Content of total solids, protein, fat, and ash and also $\mathrm{pH}$, acidity values of mare milk during 4 lactation months are reported in Table 2. The highest content of TS was obtained in June milk (11.76 g/100 g of milk), but in July milk (10.67 g/100 $\mathrm{g}$ of milk) the lowest content of TS was observed. In August (11.11 $\mathrm{g} / 100 \mathrm{~g}$ of milk) TS increased again, and in May milk (10.93 g/100 g of milk) TS was higher than in July. Protein content of mare milk was at the lowest level in milk in May $(2.20 \mathrm{~g} / 100 \mathrm{~g}$ of milk), when the pasture growing season tends to start. The highest content of protein was determined in milk in July $(2.39 \mathrm{~g} / 100$ $\mathrm{g}$ of milk) when herbage reaches its maximum yield and feeding quality. In June, protein content was lower than in July milk (2.37 g/100 g of milk), but higher than in August milk (2.29 g/100 g of milk). Because of low night temperatures, pasture growth stops in the autumn and therefore a decrease in protein content is observed. Changes in fat content of mare milk during 4 lactation months changed similar to TS. The lowest content of fat was obtained in May milk $(1.29 \mathrm{~g} / 100 \mathrm{~g}$ of milk), but in June it was at the highest level (1.90 $\mathrm{g} / 100 \mathrm{~g}$ of milk). In July milk, fat content was higher $(1.30 \mathrm{~g} / 100 \mathrm{~g}$ of milk) than in May but lower than in

Table 2. Composition and physical properties of mare milk during 4 milking months

\begin{tabular}{|c|c|c|c|c|}
\hline \multirow[b]{2}{*}{ Parameter } & \multicolumn{4}{|c|}{ Lactation month } \\
\hline & May & June & July & August \\
\hline $\begin{array}{l}\mathrm{TS}, \mathrm{g} / 100 \mathrm{~g} \\
\text { Protein, } \mathrm{g} / 100 \mathrm{~g} \\
\text { Fat, g/100 g } \\
\text { Ash, g/100 g } \\
\text { pH } \\
\text { Titratable acidity, }{ }^{\circ} \mathrm{Th} \\
\text { (Thörner degrees) }\end{array}$ & $\begin{array}{r}10.93^{\mathrm{C}} \pm 0.02 \\
2.20^{\mathrm{D}} \pm 0.01 \\
1.29^{\mathrm{D}} \pm 0.01 \\
0.46^{\mathrm{A}} \pm 0.00 \\
6.76^{\mathrm{C}} \pm 0.01 \\
5.1^{\mathrm{C}} \pm 0.09\end{array}$ & $\begin{array}{r}11.76^{\mathrm{A}} \pm 0.02 \\
2.37^{\mathrm{B}} \pm 0.01 \\
1.90^{\mathrm{A}} \pm 0.00 \\
0.43^{\mathrm{B}} \pm 0.00 \\
6.89^{\mathrm{A}} \pm 0.01 \\
5.97^{\mathrm{A}} \pm 0.05\end{array}$ & $\begin{array}{r}10.67^{\mathrm{D}} \pm 0.00 \\
2.39^{\mathrm{A}} \pm 0.02 \\
1.30^{\mathrm{C}} \pm 0.00 \\
0.40^{\mathrm{C}} \pm 0.01 \\
6.80^{\mathrm{B}} \pm 0.02 \\
5.53^{\mathrm{B}} \pm 0.05\end{array}$ & $\begin{array}{r}11.11^{\mathrm{B}} \pm 0.02 \\
2.29^{\mathrm{C}} \pm 0.00 \\
1.60^{\mathrm{B}} \pm 0.00 \\
0.30^{\mathrm{D}} \pm 0.00 \\
6.59^{\mathrm{D}} \pm 0.02 \\
5.03^{\mathrm{C}} \pm 0.05\end{array}$ \\
\hline
\end{tabular}


Table 3. Correlation coefficient (r), limit of detection (LOD), limit of quantitation (LOQ), response factor (RF), SD of response factor, and CV values

\begin{tabular}{|c|c|c|c|c|c|c|}
\hline $\mathrm{AA}$ & $\mathrm{r}$ & $\mathrm{LOD}, \mu \mathrm{g} / \mathrm{mL}$ & $\mathrm{LOQ}, \mu \mathrm{g} / \mathrm{mL}$ & $\mathrm{RF}$ & $\mathrm{SD}$ & $\mathrm{CV}, \%$ \\
\hline Aspartic acid & 0.9992 & 0.165 & 0.500 & 1.35 & 0.0014 & 0.10 \\
\hline Glutamic acid & 0.9991 & 0.166 & 0.505 & 1.51 & 0.0017 & 0.11 \\
\hline Serine & 0.9988 & 0.195 & 0.592 & 1.08 & 0.0007 & 0.06 \\
\hline Histidine & 0.9989 & 0.177 & 0.536 & 1.71 & 0.0009 & 0.05 \\
\hline Glycine & 0.9989 & 0.184 & 0.556 & 0.82 & 0.0004 & 0.05 \\
\hline Threonine & 0.9992 & 0.161 & 0.486 & 1.18 & 0.0008 & 0.07 \\
\hline Arginine & 0.9985 & 0.215 & 0.653 & 1.90 & 0.0023 & 0.12 \\
\hline Alanine & 0.9993 & 0.146 & 0.442 & 0.95 & 0.0004 & 0.04 \\
\hline Proline & 0.9757 & 1.149 & 3.481 & 5.67 & 0.0211 & 0.37 \\
\hline Tyrosine & 0.9984 & 0.228 & 0.692 & 1.84 & 0.0037 & 0.20 \\
\hline Valine & 0.9987 & 0.201 & 0.608 & 1.26 & 0.0011 & 0.09 \\
\hline Methionine & 0.9984 & 0.224 & 0.678 & 1.64 & 0.0047 & 0.28 \\
\hline Isoleucine & 0.9964 & 0.345 & 1.045 & 1.36 & 0.0169 & 1.24 \\
\hline Leucine & 0.9987 & 0.202 & 0.611 & 1.41 & 0.0107 & 0.76 \\
\hline Tryptophan & 0.9961 & 0.188 & 0.571 & 1.55 & 0.0167 & 1.08 \\
\hline Phenylalanine & 0.9986 & 0.212 & 0.642 & 1.98 & 0.0026 & 0.13 \\
\hline Ornithine & 0.9989 & 0.191 & 0.578 & 0.99 & 0.0006 & 0.06 \\
\hline Lysine & 0.9956 & 0.384 & 1.164 & 1.04 & 0.0029 & 0.28 \\
\hline
\end{tabular}

August $(1.60 \mathrm{~g} / 100 \mathrm{~g}$ of milk). Ash content of milk changed uniformly and decreased from May to August.

\section{Analytical Parameters}

Chromatograms corresponding to AA standard solution and AA isolated from mare milk are shown in Figure 1. Correlation coefficients were higher than 0.995 except for proline at 0.976 (Table 3). The limit of detection (LOD) and limit of quantification (LOQ) were calculated according to the following equations:

$$
\begin{aligned}
& \mathrm{LOD}=3.3 \times \mathrm{SD} / \mathrm{b}, \\
& \mathrm{LOQ}=10 \times \mathrm{SD} / \mathrm{b},
\end{aligned}
$$

where SD is the standard deviation of the intercept and $\mathrm{b}$ is the slope of the regression line, obtained from the calibration curve. The LOD values were in the range of 0.146 and $1.149 \mu \mathrm{g} / \mathrm{mL}$, and LOQ values were in the range between 0.442 and $3.481 \mu \mathrm{g} / \mathrm{mL}$. Response factors were determined by injecting the derivatized standards in $0.5,1,2,3$, and $4 \mu \mathrm{g} / \mathrm{mL}$ concentrations

\begin{tabular}{|c|c|c|c|c|c|}
\hline \multirow[b]{2}{*}{$\mathrm{AA}$} & \multirow{2}{*}{$\begin{array}{c}\text { Instrumental } \\
\mathrm{n}=5^{*}\end{array}$} & \multicolumn{2}{|c|}{ Derivatization procedure* } & \multirow{2}{*}{$\begin{array}{l}\text { Method }^{*} \\
\mathrm{n}=4^{1}\end{array}$} & \multirow[b]{2}{*}{ Recovery, ${ }^{*} \%$} \\
\hline & & Intraday $\mathrm{n}=3^{2}$ & Interday $\mathrm{n}=5^{2}$ & & \\
\hline Aspartic acid & 0.23 & 1.03 & 2.62 & 0.29 & $104.4 \pm 1.7$ \\
\hline Glutamic acid & 0.17 & 1.28 & 2.78 & 0.26 & $96.8 \pm 0.1$ \\
\hline Serine & 0.11 & 1.30 & 2.60 & 0.35 & $110.1 \pm 0.1$ \\
\hline Histidine & 0.10 & 0.96 & 2.44 & 2.32 & $104.3 \pm 0.6$ \\
\hline Glycine & 0.06 & 2.09 & 1.61 & 1.94 & $100.6 \pm 0.1$ \\
\hline Threonine & 0.15 & 1.41 & 1.43 & 1.18 & $96.1 \pm 0.2$ \\
\hline Arginine & 0.07 & 1.08 & 2.58 & 0.30 & $99.1 \pm 0.5$ \\
\hline Alanine & 0.10 & 1.12 & 2.59 & 0.41 & $103.9 \pm 0.1$ \\
\hline Proline & 1.00 & 2.46 & 2.46 & 1.59 & $70.0 \pm 8.4$ \\
\hline Tyrosine & 0.08 & 0.88 & 2.40 & 0.73 & $112.5 \pm 0.5$ \\
\hline Valine & 0.16 & 1.07 & 2.58 & 0.99 & $97.9 \pm 0.3$ \\
\hline Methionine & 0.17 & 1.96 & 1.78 & 3.27 & $139.0 \pm 0.5$ \\
\hline Isoleucine & 0.21 & 1.23 & 2.62 & 1.10 & $114.8 \pm 0.1$ \\
\hline Leucine & 0.54 & 0.88 & 2.53 & 3.19 & $95.1 \pm 4.0$ \\
\hline Tryptophan & 0.16 & 1.60 & 2.80 & 4.40 & $95.4 \pm 12.1$ \\
\hline Phenylalanine & 0.34 & 1.11 & 2.61 & 0.62 & $98.2 \pm 0.1$ \\
\hline Ornithine & 0.12 & 1.07 & 2.55 & 4.88 & $87.5 \pm 0.4$ \\
\hline Lysine & 0.09 & 0.82 & 2.48 & 0.34 & $95.8 \pm 1.1$ \\
\hline
\end{tabular}

Table 4. Instrumental, derivatization procedure, and method precision (relative SD) and recovery values $( \pm \mathrm{SD})$

${ }^{1}$ Estimated with sample.

${ }^{2}$ Estimated with standard.

*Significant at $P<0.05$. 

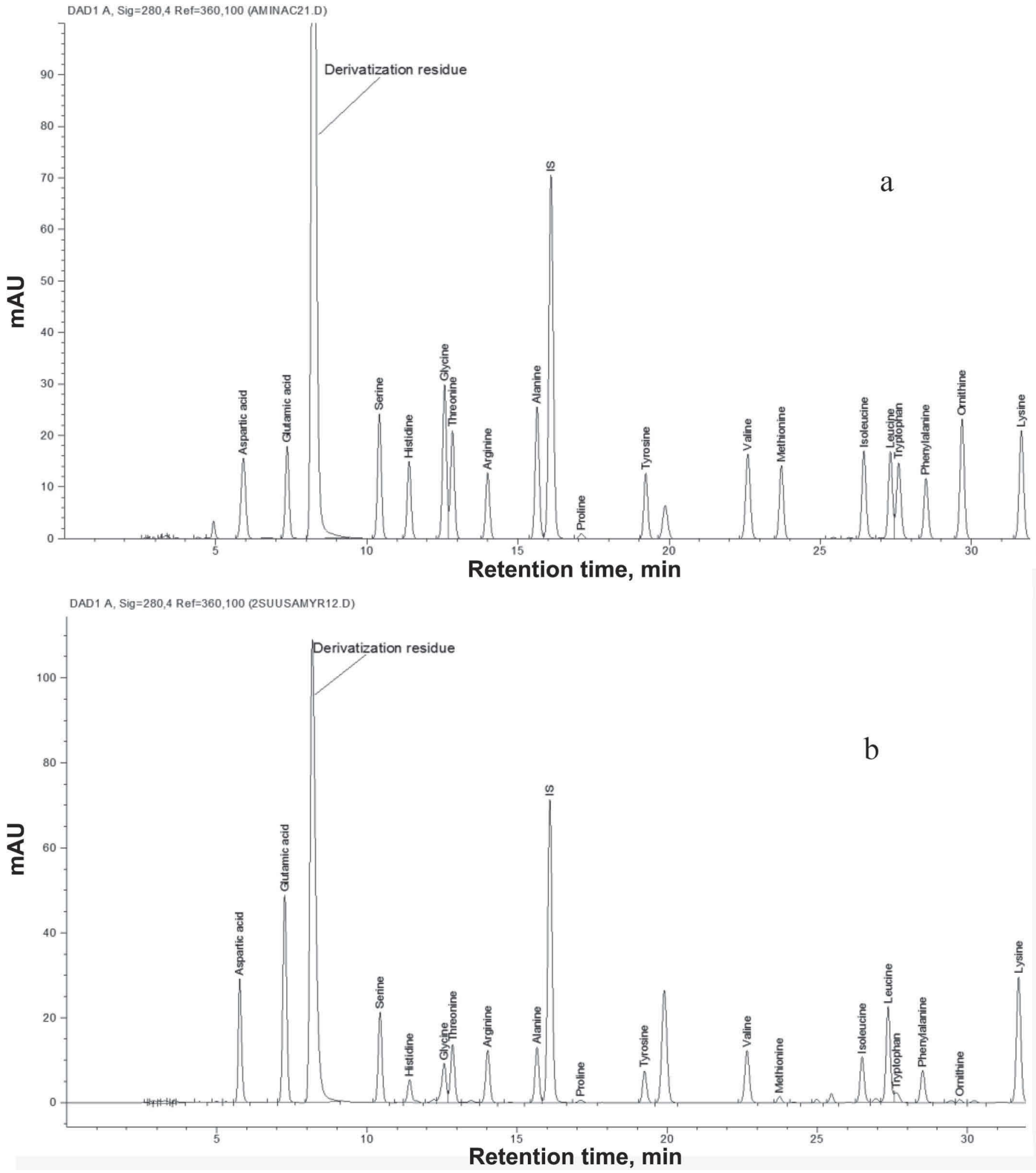

Figure 1. Typical chromatograms for (a) AA standard solution and (b) AA isolated from mare milk. IS = internal standard. AU = absorbance units. 


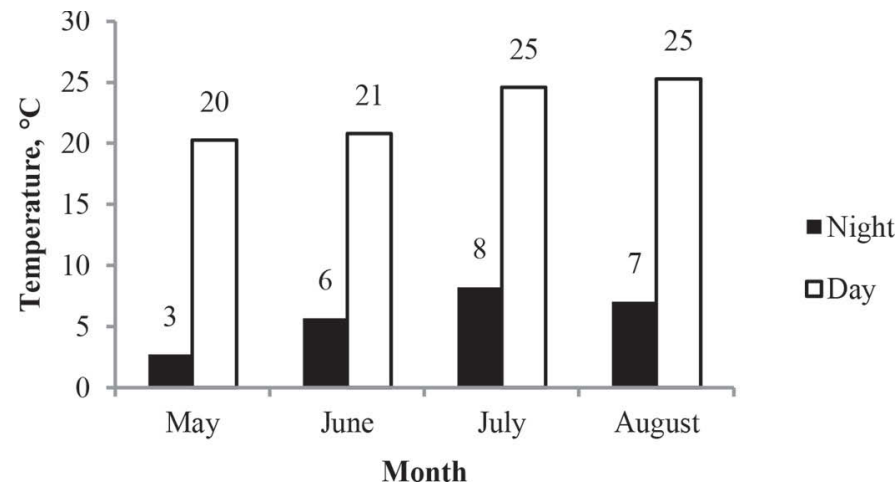

Figure 2. The monthly average temperature in Suusamyr pasture for 2014 .

with an internal standard $(3 \mu \mathrm{g} / \mathrm{mL})$ several times on different days. The values obtained are reported in Table 3. Standard deviation values for response factors were lower than 0.0211 .

The results of instrumental, derivatization procedure and method precision, expressed as relative standard deviation, are reported in Table 4 . Instrumental precision was calculated based on area of standard with 5 injections of one derivatized standard. The relative standard deviation values for instrumental precision were in the range of 0.07 to 1.00 , for derivatization procedure 0.82 to 2.80 and for method 0.26 to 4.88 . To test the accuracy of the method, known amounts of standards, were added to the hydrolyzed sample. Amino acids were measured in the spiked and the unspiked samples and recoveries were calculated. The assays were carried out in triplicates. The average recovery values of AA ranged from 87.5 to $114.8 \%$. The recoveries are better than reported in literature (Bosch et al., 2006; Rebane and Herodes, 2010).

\section{AA Composition}

Amino acid contents of mare milk (g/100 g of milk) during 4 lactation months are reported in Table 5. Concentrations of aspartic acid, glutamic acid, serine, histidine, glycine, threonine, arginine, alanine, tyrosine, and leucine reached their maximum levels in June. Contents of proline, methionine, and tryptophan were at the highest level in July milk. Concentration of valine was at the highest level in August milk, and isoleucine was not changed in June, July, and August and slightly decreased in May. Phenylalanine content was at the highest degree in June and July and ornithine content in July and August milk. Lysine content was not changed according to milking months. In May milk, no one AA was at the highest concentration, which was due to the lowest daylight and night average temperature (Figure 2). Generally, the temperature does not exceed $25^{\circ} \mathrm{C}$ in this region; it is rainy, and pasture is always covered with green grasses (http://suusamyr.nuipogoda.ru). The stage of maturity of the available herbage varies according to water supply and climatic conditions.

Table 5. Amino acid composition (g of AA/100 g of milk) of mare milk during 4 lactation months ${ }^{1}$

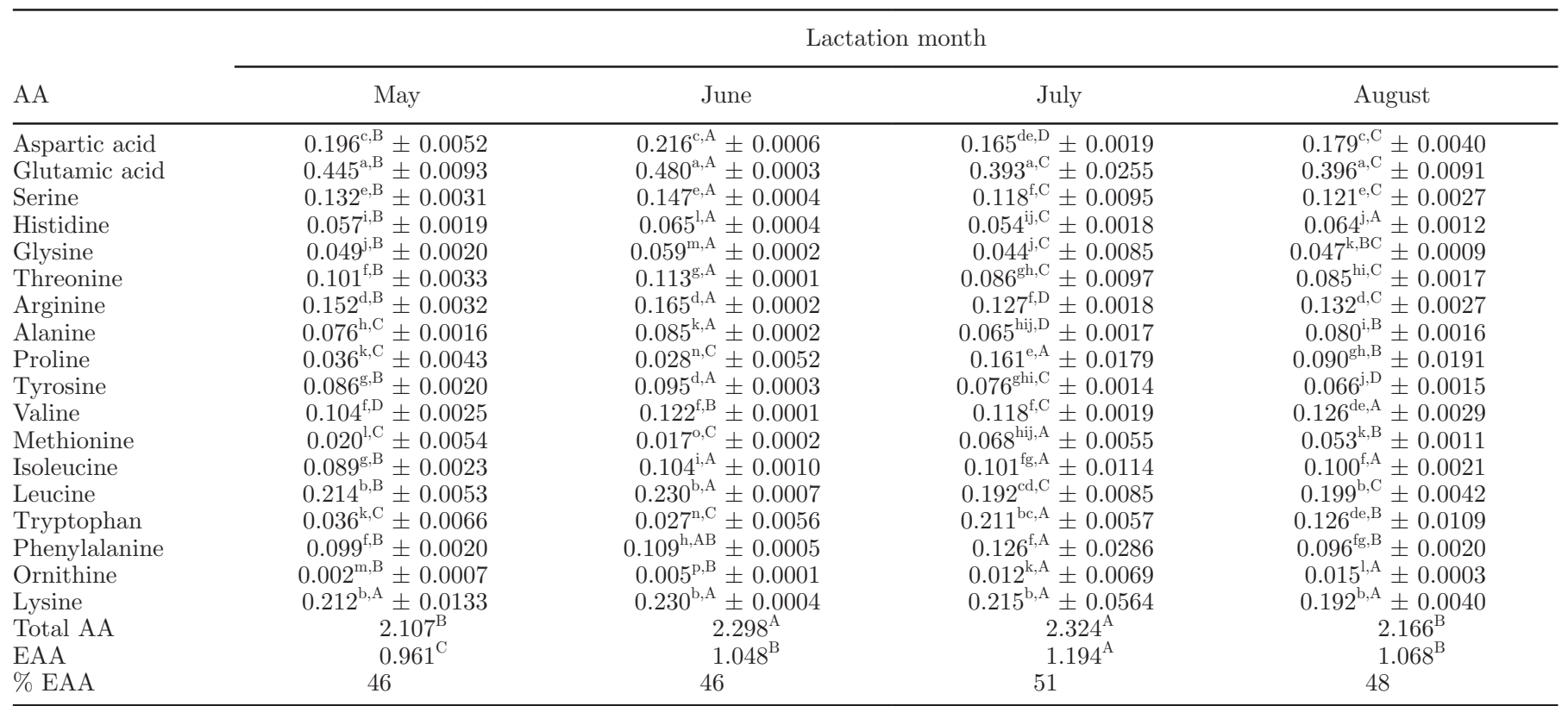

${ }^{\mathrm{a}-\mathrm{p}}$ Differences within the AA content are statistically significant $(P=0.01)$.

${ }^{\mathrm{A}-\mathrm{D}}$ Differences within the lactation months are statistically significant $(P=0.01)$.

${ }^{1}$ Mean \pm SD. 
Table 6. Amino acid content of mare milk as grams of AA per $100 \mathrm{~g}$ of protein during 4 lactation months ${ }^{1}$

\begin{tabular}{|c|c|c|c|c|}
\hline \multirow[b]{2}{*}{ AA } & \multicolumn{4}{|c|}{ Lactation month } \\
\hline & May & June & July & August \\
\hline Aspartic acid & $9.33^{\mathrm{c}, \mathrm{A}} \pm 0.24$ & $9.40^{\mathrm{c}, \mathrm{A}} \pm 0.02$ & $7.07^{\mathrm{de}, \mathrm{C}} \pm 0.08$ & $8.26^{\mathrm{c}, \mathrm{B}} \pm 0.18$ \\
\hline Glutamic acid & $21.11^{\mathrm{a}, \mathrm{A}} \pm 0.44$ & $20.86^{\mathrm{a}, \mathrm{A}} \pm 0.01$ & $16.83^{\mathrm{a}, \mathrm{C}} \pm 1.09$ & $18.26^{\mathrm{a}, \mathrm{B}} \pm 0.42$ \\
\hline Serine & $6.28^{\mathrm{e}, \mathrm{A}} \pm 0.15$ & $6.41^{\mathrm{e}, \mathrm{A}} \pm 0.02$ & $5.07^{\mathrm{f}, \mathrm{C}} \pm 0.41$ & $5.57^{\mathrm{e}, \mathrm{B}} \pm 0.12$ \\
\hline Histidine & $2.72^{\mathrm{i}, \mathrm{C}} \pm 0.09$ & $2.84^{1, \mathrm{~B}} \pm 0.02$ & $2.29^{\mathrm{ij}, \mathrm{D}} \pm 0.08$ & $2.95^{\mathrm{j}, \mathrm{A}} \pm 0.05$ \\
\hline Glysine & $2.33^{\mathrm{j}, \mathrm{A}} \pm 0.09$ & $2.58^{\mathrm{m}, \mathrm{A}} \pm 0.01$ & $1.89^{\mathrm{j}, \mathrm{C}} \pm 0.36$ & $2.17^{\mathrm{k}, \mathrm{B}} \pm 0.04$ \\
\hline Threonine & $4.78^{\mathrm{e}, \mathrm{A}} \pm 0.16$ & $4.89^{\mathrm{j}, \mathrm{A}} \pm 0.00$ & $3.70^{\mathrm{gh}, \mathrm{B}} \pm 0.42$ & $3.91^{\mathrm{hi}, \mathrm{B}} \pm 0.08$ \\
\hline Arginine & $7.21^{\mathrm{d}, \mathrm{A}} \pm 0.15$ & $7.17^{\mathrm{d}, \mathrm{A}} \pm 0.01$ & $5.45^{\mathrm{f}, \mathrm{C}} \pm 0.08$ & $6.08^{\mathrm{d}, \mathrm{B}} \pm 0.13$ \\
\hline Alanine & $3.59^{\mathrm{h}, \mathrm{B}} \pm 0.08$ & $3.70^{\mathrm{k}, \mathrm{A}} \pm 0.01$ & $2.77^{\mathrm{hij}, \mathrm{C}} \pm 0.07$ & $3.70^{\mathrm{i}, \mathrm{A}} \pm 0.07$ \\
\hline Proline & $1.69^{\mathrm{k}, \mathrm{C}} \pm 0.20$ & $1.22^{\mathrm{n}, \mathrm{C}} \pm 0.23$ & $6.89^{\mathrm{e}, \mathrm{A}} \pm 0.77$ & $4.14^{\mathrm{gh}, \mathrm{B}} \pm 0.88$ \\
\hline Tyrosine & $4.08^{\mathrm{g}, \mathrm{A}} \pm 0.09$ & $4.13^{\mathrm{j}, \mathrm{A}} \pm 0.01$ & $3.26^{\mathrm{ghi}, \mathrm{B}} \pm 0.06$ & $3.06^{\mathrm{j}, \mathrm{C}} \pm 0.07$ \\
\hline Valine & $4.91^{\mathrm{e}, \mathrm{D}} \pm 0.12$ & $5.30^{\mathrm{f}, \mathrm{B}} \pm 0.01$ & $5.06^{\mathrm{f}, \mathrm{C}} \pm 0.08$ & $5.80^{\mathrm{de}, \mathrm{A}} \pm 0.14$ \\
\hline Methionine & $0.97^{1, \mathrm{C}} \pm 0.26$ & $0.76^{\mathrm{o}, \mathrm{C}} \pm 0.01$ & $2.91^{\mathrm{hij}, \mathrm{A}} \pm 0.24$ & $2.45^{\mathrm{k}, \mathrm{B}} \pm 0.05$ \\
\hline Isoleucine & $4.24^{\mathrm{f}, \mathrm{A}} \pm 0.11$ & $4.54^{\mathrm{i}, \mathrm{A}} \pm 0.04$ & $4.35^{\mathrm{fg}, \mathrm{A}} \pm 0.49$ & $4.63^{\mathrm{f}, \mathrm{A}} \pm 0.10$ \\
\hline Leucine & $10.15^{\mathrm{b}, \mathrm{A}} \pm 0.25$ & $9.94^{\mathrm{b}, \mathrm{A}} \pm 0.14$ & $8.24^{\mathrm{cd}, \mathrm{C}} \pm 0.37$ & $9.18^{\mathrm{b}, \mathrm{B}} \pm 0.19$ \\
\hline Tryptophan & $1.71^{\mathrm{j}, \mathrm{C}} \pm 0.32$ & $1.26^{\mathrm{n}, \mathrm{C}} \pm 0.08$ & $9.03^{\mathrm{bc}, \mathrm{A}} \pm 0.25$ & $5.81^{\mathrm{de}, \mathrm{B}} \pm 0.50$ \\
\hline Phenylalanine & $4.69^{\mathrm{f}, \mathrm{A}} \pm 0.10$ & $4.76^{\mathrm{h}, \mathrm{A}} \pm 0.02$ & $5.42^{\mathrm{f}, \mathrm{A}} \pm 1.23$ & $4.44^{\mathrm{fg}, \mathrm{A}} \pm 0.09$ \\
\hline Ornithine & $0.12^{\mathrm{m}, \mathrm{B}} \pm 0.04$ & $0.23^{\mathrm{p}, \mathrm{B}} \pm 0.00$ & $0.53^{\mathrm{k}, \mathrm{A}} \pm 0.29$ & $0.68^{1, \mathrm{~A}} \pm 0.01$ \\
\hline Lysine & $10.08^{\mathrm{b}, \mathrm{A}} \pm 0.63$ & $10.00^{\mathrm{b}, \mathrm{A}} \pm 0.02$ & $9.24^{\mathrm{b}, \mathrm{A}} \pm 2.42$ & $8.87^{\mathrm{b}, \mathrm{A}} \pm 0.19$ \\
\hline
\end{tabular}

The most abundant AA in mare milk is glutamic acid $(0.393-0.480 \mathrm{~g} / 100 \mathrm{~g}$ of milk). Its concentration stays at the highest level for all the milking season and it is about 2 times that of aspartic acid $(0.165-0.216 \mathrm{~g} / 100$ $\mathrm{g}$ of milk), leucine $(0.192-0.230 \mathrm{~g} / 100 \mathrm{~g}$ of milk), lysine $(0.212-0.230 \mathrm{~g} / 100 \mathrm{~g}$ of milk) and about 3 times of serine (0.118-0.147) and arginine (0.127-0.165 g/100 $\mathrm{g})$. The sums of total AA were higher in June and July, but the sum of EAA and content of EAA in the protein fraction was highest in July milk.

When the AA composition was expressed as grams of AA/100 g of protein, concentrations of AA of May and June milks were approximately at the same levels except of histidine, alanine, and valine (Table 6). Content of EAA isoleucine, phenylalanine, and lysine are not changed during 4 mo. Other EAA such as threonine, tyrosine, and leucine were close in May and June. Only the EAA valine was at the highest level in August. Two other EAA methionine and tryptophan contents were higher in July than milk from other months. Data for the AA composition of milk protein, with the exception of tryptophan, lysine, and proline agree with results of Csapó-Kiss et al. (1995), Davis et al. (1994), and Marconi and Panfili (1998). The tryptophan contents of mare milk samples were higher in May, July, and August milks and the same for June milk compared with the values reported by Csapó-Kiss et al. (1995). The lysine content of the milk samples was higher than that reported by other authors (Csapó-Kiss et al., 1995; Davis et al., 1994; Marconi and Panfili, 1998).
The AA content of mare milk of highlands was twice the AA content of mare milk from the Mongolia Gobi steppe, steppe, and forest steppe regions (Minjigdorj et al., 2012).

\section{CONCLUSIONS}

The HPLC method by precolumn derivatization with DEEMM used in the current study enabled the separation and quantification of $18 \mathrm{AA}$ in milk from mares grazing on the highlands of the Kyrgyz Republic. The percentages of EAA in the protein of mare milk remained at high levels throughout the 4 milking months. The favorable grazing conditions of pasture throughout the milking season result in high-quality mare milk proteins.

\section{ACKNOWLEDGMENTS}

This study was financially supported by Kyrgyz Turkish Manas University (Bishkek, Kyrgyz Republic). The authors thank the Baytur horse farm (Suusamyr pasture, Chuy Province, Kyrgyz Republic) for providing the samples and Coskan Ilicali (Kyrgyzstan-Turkey Manas University, Bishkek, Kyrgyz Republic) for revising the English manuscript.

\section{REFERENCES}

AOAC International. 2000. Official Methods of Analysis of AOAC International, 17th ed. AOAC International, Rockville, MD. 
Bosch, L., A. Alegria, and R. Farre. 2006. Application of the 6-aminoquinolyl-N-hydroxysccinimidyl carbamate (AQC) reagent to the RP-HPLC determination of amino acids in infant foods. J. Chromatogr. B Analyt. Technol. Biomed. Life Sci. 831:176-183.

Čagalj, M., A. Brezovečki, N. Mikulec, and N. Antunac. 2014. Composition and properties of mare's milk. Mljekarstvo 64:3-11.

Cagno, R. D., A. Tamborrino, G. Gallo, C. Leone, M. D. Angelis, M. Faccia, P. Amirante, and M. Gobbetti. 2004. Uses of mares' milk in manufacture of fermented milks. Int. Dairy J. 14:767-775.

CIS. 2001. State Standard 3624-92. Milk and milk products. Titrimetric methods of acidity determination. Intergovernmental standard, Commonwealth of Independent States (CIS), Minsk, Belarus. Standartinform Publishers, Moscow, Russia. (In Russian.)

Csapó-Kiss, Zs., J. Stefler, T. G. Martin, S. Makray, and J. Csapó. 1995. Composition of mare's colostrums and milk II. Protein content, amino acid composition and contents of macro- and microelements. Int. Dairy J. 5:403-415.

Davis, T. A., H. V. Nguyen, R. Garcia-Bravo, M. L. Fiorotto, E. M. Jacksonz, and P. J. Reeds. 1994. Amino acid composition of the milk of some mammalian species changes with stage of lactation. Br. J. Nutr. 72:845-853.

Doreau, M., and S. Boulot. 1989. Recent knowledge on mare milk production. Livest. Prod. Sci. 22:213-235. (review).

Doreau, M., and F. Martuzzi. 2006. Fat content and composition of mare's milk. Page 78 in Nutrition and Feeding of the Broodmare. Proc. 3rd Eur. Workshop Equine Nutr. EAAP Publication No. 120. N. Miraglia and W. Martin-Rosset, ed. Wageningen Academic Publishers, Wageningen, the Netherlands.

Fox, P. F., and P. L. H. McSweeney. 1998. Dairy Chem BioChem. Chapman and Hall, London, UK.

Hambraus, L. 1993. Milk composition in animals and humans: Nutritional aspects. Pages 13-25 in Proceedings of 1st World Congress of Dairy Products in Human Health and Nutrition. 1994. CRC Press, Balkema Rotterdam, the Netherlands.

Hermosin, I., R. M. Chicon, and M. D. Cabezudo. 2003. Free amino acid composition and botanical origin of honey. Food Chem. 83:263-268. http://suusamyr.nuipogoda.ru/.

Kucukcetin, A., H. Yaygin, J. Hinrichs, and U. Kulozik. 2003. Adaptation of bovine milk towards mares' milk composition by means of membrane technology for koumiss manufacture. Int. Dairy J. 13:945-951.

Lv, J., and L. M. Wang. 2009. Bioactive components in kefir and koumiss. Pages 252-253 3 in Bioactive Components in Milk and Dairy Products. Blackwell Professional Publishing, Ames, IA.

Malacarne, M., F. Martuzzi, A. Summer, and P. Mariani. 2002. Review. Protein and fat composition of mare's milk: Some nutritional remarks with reference to human and cow's milk. Int. Dairy J. $12: 869-877$

Marconi, E., and G. Panfili. 1998. Chemical composition and nutritional properties of commercial products of mare milk powder. J. Food Compos. Anal. 11:178-187.

Marino, R., M. Iammarino, A. Santillo, M. Muscarella, M. Caroprese, and M. Albenzio. 2010. Technical note: Rapid method for determination of amino acids in milk. J. Dairy Sci. 93:2367-2370.

Minjigdorj, N., O. Baldorj, and D. Austbø. 2012. Chemical composition of Mongolian mare milk. Acta Agric. Scand. A 62:66-72.

O'Mahony, J. A., and P. F. Fox. 2014. Milk: An overview. Pages 26 and 60 in Milk Proteins: From Expression to Food. 2nd ed. Academic Press, Cambridge, MA.

Park, Y. W. 2009. Overview of Bioactive Components in Milk and Dairy Products. Page 3 in Bioactive Components in Milk and Dairy Products. Blackwell Professional Publishing. Ames, IA.

Potočnik, K., V. Gantner, K. Kuterovac, and A. Cividini. 2011. Mare's milk: Composition and protein fraction in comparison with different milk species. Mljekarstvo 61:107-113. (Review).

Rebane, R., and K. Herodes. 2010. A sensitive method for free amino acids analysis by liquid chromatography with ultraviolet and mass spectrometric detection using precolumn derivatization with diethyl ethoxymethylenemalonate: Application to the honey analysis. Anal. Chim. Acta 672:79-84.

Rubio-Barroso, S., M. J. Santos-Delgado, C. Martın-Olivar, and L. M. Polo-Diez. 2006. Indirect chiral HPLC determination and fluorimetric detection of D-amino acids in milk and oyster samples. J. Dairy Sci. 89:82-89.

Rudenko, A. O., L. A. Kartsova, and S. I. Snarskiy. 2009. Determination of the most important amino acids in complex biological objects using RP-HPLC after derivatization with phenylisothiocyanate. Sorbs. Chromat. Pros. 10:2.

Sabahelkheir, M. K., M. M. Fat, and A. A. Hassan. 2012. Amino acid composition of human and animal's milk (camel, cow, sheep and goat). ARPN J. Sci. Technol. 2:32-34.

Stanton. C., D. McMahon, and S. Mills. 2013. Dairy components, products and human health. Chapter 5 in Milk and Dairy Products In Human Nutrition. FAO, Rome, Italy.

WHO. 2002. Protein and amino acid requirements in human nutrition. Report of a Joint WHO/FAO/UNU Expert Consultation. Technical Report Series No. 935

Zhan, H., X. Chen, T. Dan, and J. Dong. 2014. Traditional Chinese Fermented Dairy Foods. Chapter 8 in Lactic Acid Bacteria: Fundamentals and Practice. H. Zhang and Y. Cai, ed. Springer Science+Business Media Dordrecht, Germany. 